\title{
La empresa automotriz IASFSA en Santa Fe. Características de una experiencia en los márgenes (1959-1969) ${ }^{1}$
}

\author{
Enzo Vicentin \\ Centros de Estudios Sociales \\ Interdisciplinarios del Litoral - \\ Consejo Nacional de Investigaciones \\ Científicas y Técnicas \\ enzovicentin@hotmail.com
}

\begin{abstract}
Resumen
La industria automotriz en Argentina experimentó significativos cambios hacia finales de la década de 1950. Dentro de la nueva conformación que va adquiriendo el sector durante los ' 60 , este trabajo centra su interés en IASFSA, una empresa en la que la firma alemana DKW se asoció con inversionistas locales para producir automotores de la marca "Auto Union". Esta empresa que se instaló en la provincia de Santa Fe, participó en el mercado hasta 1969, fabricó cerca de 33000 automotores y llegó a emplear a 1500 trabajadores, transformándose en una de las industrias más importantes de la región central de la provincia. A través de documentos de la propia empresa, entrevistas a ex trabajadores, legislación nacional y provincial de promoción industrial, revistas y periódicos de la época y bibliografía específica sobre la industria automotriz, el trabajo busca describir las distintas etapas de IASFSA desde su radicación hasta su crisis definitiva cerrada con la venta de su planta industrial a Fiat. En este marco, intentamos argumentar que aunque IASFSA siguió un patrón de comportamiento común a otras empresas del sector, algunas características específicas relacionadas a su ubicación geográfica, a la composición de su conducción y a su trayectoria en el mercado, hicieron de esta empresa una experiencia singular dentro de la industria automotriz en la década del ' 60 .
\end{abstract}

Palabras clave: IASFSA - Industria Automotriz - Desarrollismo

1 El siguiente artículo presenta una parte de los resultados de la investigación realizada en nuestra tesis de grado, donde abordamos el impacto de las políticas de promoción industrial del Estado santafesino y de la relación capital-trabajo dentro de la empresa sobre el desarrollo de IASFSA. A su vez, aquí retomamos con modificaciones algunos temas desarrollados en un trabajo presentado en el marco de las III Jornadas de la Historia de la Historia de la Industria y los Servicios, organizadas por la Facultad de Ciencias Económicas, UBA, en 2011.

VICENTIN, Enzo. "La empresa automotriz IASFSA en Santa Fe. Características de una experiencia en los márgenes (1959-1969)" en Avances del Cesor, Año X, $\mathrm{N}^{\circ} 10,2013$, pp. 9-33. 


\begin{abstract}
The automotive industry in Argentina experienced significant changes in the late 50s. Within the new conformation of the sector during the 60s, this paper focuses its interest in IASFSA, a company in which the German firm DKW partnered with local investors to produce cars brand "Auto Union". This company was installed in Santa Fe Province, participated in the market until 1969, produced about 33,000 vehicles and employed up to 1,500 workers, transforming into one of the most important industries in the central region of the province. Through the company documents, interviews with former employees, national and provincial industrial promotion, magazines and newspapers of the time and specific literature on the automotive industry, the paper aims to describe the different stages of IASFSA since its establishment until its final crisis closed with the sale of its industrial plant to Fiat. In this framework, we try to argue that although IASFSA followed a pattern common to other companies, some specific features related to its geographic location, the composition of his leadership and his trajectory in the market, made this company a unique experience within automotive industry in the 60s.
\end{abstract} Key Words: IASFSA - Automotive Industry - Developmentalism

\title{
Introducción
}

A partir del programa económico desarrollista encarado por el gobierno de Arturo Frondizi (1958-1962), el sector industrial inició un ciclo de profundas transformaciones. El modelo concebido por el gobierno de la Unión Cívica Radical Intransigente (UCRI) surgió de un diagnóstico que hizo hincapié en el desbalance de la estructura industrial debido a la falta de desarrollo de las industrias básicas, la insuficiencia del ahorro interno y la escasez de divisas derivada de la crisis permanente del sector externo. Argumentando que el ritmo del desarrollo debía ser acelerado, el desarrollismo propuso avanzar en la industrialización por sustitución de importaciones (ISI) fomentando las industrias productoras de insumos básicos y de bienes de consumo durables. Las inversiones extranjeras ocuparon dentro de este proyecto un espacio fundamental, ya que en la óptica del gobierno venían a elevar el bajo nivel de inversión local en el sector industrial y a modernizar los procesos de trabajo a través de organizaciones y tecnologías propias de economías desarrolladas. ${ }^{2}$ La rama automotriz se ubicó dentro de las prioridades de la política económica, ya que era valorada por sus efectos multiplicadores sobre otros sectores de la economía. El decreto 3693/59 del Poder Ejecutivo Nacional (PEN), titulado Régimen de Promoción de la Industria Automotriz, fijó medidas de promoción directas para la producción local de automotores. Este programa sectorial se

2 SCHVARZER, Jorge, La industria que supimos conseguir, Planeta, Buenos Aires, 1996; SOURROUILLE, Juan, KOSACOFF Bernardo y LUCANGELI, Jorge, Transnacionalización y política económica en la Argentina, Centro de Economía Transnacional, Centro Editor de América Latina, Buenos Aires, 1985. 
ubicaba dentro del marco de las leyes 14780 (de inversión de capitales extranjeros) y 14781 (de promoción industrial), instrumentos centrales de la política económica desarrollista.

Las transformaciones generadas en la industria automotriz desde finales de la década del ' 50 se vieron reflejadas en un acelerado crecimiento de las ventas en el mercado interno, la multiplicación de plantas terminales y el rápido crecimiento del empleo en el sector y en los subsectores asociados. En la historiografía que aborda la industria automotriz argentina ${ }^{3}$ existe consenso en señalar que con el desarrollismo se abrió una nueva etapa para el sector, cualitativamente distinta respecto a sus etapas previas y de profundas consecuencias para su posterior desarrollo. A nivel del sector industrial en general, se reconoce que las iniciativas económicas del desarrollismo modificaron sustancialmente el tejido industrial del país. Una de las características más destacadas fue el aumento de la participación del capital extranjero en el sector. ${ }^{4}$ Las inversiones, predominantemente estadounidenses, tuvieron como destino

3 BARANSON, Jack, La industria automotriz en los países en desarrollo, Tecnos, Madrid, 1971; REMES LENICOV, Jorge, "Algunos resultados de la política desarrollista: el caso de la industria automotriz”, en Jornadas de economía: problemas económicos argentinos, diagnósticos y políticas, Macchi, Buenos Aires, 1974; COSCIA, Santiago, Evolución, dinámica actual y perspectivas de la industria automotriz. Estudio sectorial, Banco Nacional de Desarrollo, Buenos Aires, 1980; SOURROUILLE, Juan, Transnacionales en América Latina. El complejo automotor en Argentina, Nueva Imagen, México, 1980; NOFAL, Beatriz, Absentee entrepreneurship and the dynamics of the motor vehicle industry in Argentina, Praeger, Nueva York, 1989; IANNI, Valeria, "La especificidad del desarrollo de la industria automotriz en la Argentina, 1959-1963”, en Estudos Ibero-Americanos, Pontifícia Universidade Católica do Rio Grande do Sul, Porto Alegre, 2008, Vol. XXXIV, №. 2. Desde perspectivas de análisis del conjunto del sector industrial también se ha analizado la trayectoria de la industria automotriz en esos años. Al respecto, SCHVARZER, Jorge, La industria que..., Op. Cit.; DORFMAN, Adolfo, Cincuenta años de industrialización en la Argentina, 1930-1980, Solar, Buenos Aires, 1983.

4 Observando la totalidad de la segunda etapa de la ISI, entre 1953 y 1976, bajo el régimen establecido por la ley 14780 (1958-1970) se autorizaron inversiones extranjeras por 744 millones de dólares. Mientras que en el período 1953-1958 bajo otras normas jurídicas se autorizaron 54 millones, y entre 1970 y 1973 unos 35 millones. Dentro del período de vigencia de la ley 14780, "entre 1959 y 1962 se autorizaron radicaciones por un valor de 500 millones de dólares, monto que duplica la suma de todas las autorizaciones concedidas entre 1954 y 1958 y entre 1963 y 1970" en SOURROUILLE, Juan, KOSACOFF Bernardo y LUCANGELI, Jorge, Transnacionalización y política económica..., Op. Cit., p. 26. 
las ramas más dinámicas de la producción. ${ }^{5} \mathrm{El}$ sector industrial de la provincia de Santa $\mathrm{Fe}$ siguió el mismo patrón nacional, transformándose cuantitativa y cualitativamente. ${ }^{6}$

Dentro de la industria automotriz argentina durante la década de 1960, nuestro trabajo focaliza su interés en Industria Automotriz Santa Fe S.A. (IASFSA), empresa en la que la firma alemana DKW se asoció con inversionistas locales para producir automotores de la marca Auto Union. IASFSA se instaló en la ciudad de Santa Fe y luego en Sauce Viejo (localidad ubicada a $25 \mathrm{~km}$. de la capital provincial), participó en el mercado local hasta 1969, fabricó cerca de 33000 automotores y llegó a emplear a 1500 trabajadores, transformándose en uno de los emprendimientos industriales más importantes de la región central de la provincia. La hipótesis central que recorre este artículo es que IASFSA siguió en la década del ' 60 un patrón de comportamiento común a otras empresas del sector, pero al mismo tiempo fue un caso singular por haber sido la única automotriz radicada en la provincia de Santa Fe, por la particular composición de su capital y su Directorio, y por haber sido una de las terminales con bajo volumen de producción que más tiempo se mantuvo dentro del mercado. Estas características específicas de IASFSA la convierten en una experiencia particular dentro de la industria automotriz de la época.

Iniciamos este trabajo describiendo la instalación de IASFSA en Santa Fe y la composición de su capital social y Directorio, así como la relación establecida con DKW de Alemania. Luego pasamos a analizar su producción y posición dentro del mercado local. Posteriormente, nos enfocamos en una serie de elementos relacionados a la organización interna de la firma, para después adentrarnos en su evolución económico-financiera. Por último, describimos la crisis definitiva de la empresa y finalizamos el trabajo estableciendo algunas conclusiones sobre este estudio de caso. Las fuentes consultadas incluyen documentación perteneciente a la empresa, legislación provincial y nacional específica, periódicos de la ciudad de Santa Fe,

5 De las inversiones aprobadas entre 1959 y 1962, “el 90\% de ellas se concentró en las industrias químicas, petroquímicas y derivados del petróleo, material de transporte, metalurgia y maquinarias eléctricas y no eléctricas." Ibídem. El capital proveniente de Estados Unidos representó el 60\% de la inversión extranjera entre 1958 y 1962. Cabe aclarar que este rasgo no se limitó a los años del gobierno de Frondizi, sino que operó a lo largo de toda la segunda etapa de la ISI AZPIAZU, Daniel, "Las empresas transnacionales en la Argentina", en Estudios e Informes de la CEPAL, Santiago de Chile, 1986, № 56.

6 La cantidad de establecimientos industriales en la Provincia creció un 25\% entre 1960 y 1964 en VÁZQUEZ, Eladio, Política y acción industrial en la Provincia de Santa Fe, Ministerio de Hacienda, Economía e Industrias, Santa Fe, 1969. Además, creció la importancia de ramas dinámicas a partir de grandes inversiones en los sectores petroquímico, metalúrgico y automotriz. De las inversiones extranjeras autorizadas en 1958-1962, el 50\% se dirigió a la provincia de Buenos Aires, mientras que un $24 \%$ tuvo como destino Santa Fe en SIMONASSI, Silvia, "El desarrollo industrial en debate. Gobierno desarrollista y sector industrial en la provincia de Santa Fe, 1958-1962" en ROUGIER, Marcelo (director), Estudios sobre la industria argentina. Políticas de promoción y estrategias empresariales 2, Lenguaje Claro Editora, Buenos Aires, 2010. 
revistas especializadas en la industria automotriz, entrevistas a ex trabajadores de IASFSA $\mathrm{y}$ fuentes secundarias.

\section{Los orígenes de IASFSA y la composición de su dirección}

A partir del decreto 3693/59 numerosas empresas extranjeras y algunas nacionales comenzaron a planificar su entrada al mercado productor de automotores. Entre la gran cantidad de proyectos presentados (26 en total), dos se radicaron en Santa Fe. ${ }^{7}$ Para entonces, el gobierno provincial de Carlos Sylvestre Begnis (1958-1962) de la UCRI, en sintonía con el proyecto de Frondizi, buscaba la radicación de inversiones en sectores industriales dinámicos. El Instituto de Fomento Industrial (IFI) era un organismo técnico consultivo que venía desempeñando actividades en tal sentido. ${ }^{8}$ En forma paralela a la labor del IFI, en 1958 algunas entidades empresariales de la ciudad de Santa Fe crearon el Movimiento Pro-Activación Económica de Santa Fe (MAE) con el propósito de conseguir la radicación de nuevas industrias en la ciudad y sus alrededores. ${ }^{9}$

En ese contexto, en agosto de 1959 un grupo de empresarios provenientes de Buenos Aires se presentó en la ciudad de Santa Fe acompañados por miembros del MAE, para anunciar la instalación de una fábrica de automotores de la firma Wartburg S.A. (procedente de Alemania Oriental). ${ }^{10}$ Allí el Ing. Roberto Huerta (como representante de Wartburg) anticipó las principales características del proyecto: comienzo de la producción en enero de 1960; construcción de tres modelos; producción de 25000 unidades en 5 años; y empleo inicial de 300 trabajadores con vistas a alcanzar los 2000 o 2500 hacia 1964. Sin embargo, días después los empresarios locales involucrados en el proyecto anunciaron que los automotores serían finalmente de la firma Auto Union GmbH (con origen en Frankfurt, Alemania Occidental), en el marco de una visita de ingenieros alemanes de dicha firma. ${ }^{11}$ Auto Union era una empresa conjunta creada en Alemania en 1932 por el agrupamiento de las firmas Horch, Audi,

7 Además de IASFSA, Goliath Hansa Argentina proyectó su instalación en Villa Constitución para producir vehículos bajo licencia de la empresa alemana Goliath Werke. No obstante, el proyecto no prosperó y la empresa fue desafectada del programa sectorial de promoción un año después de su arribo.

8 Creado dentro del Ministerio de Hacienda, Economía e Industrias de la Provincia de Santa Fe a partir del decreto-ley 9132/56, el IFI se proponía estudiar y promover la radicación de capitales industriales en la provincia, realizar campañas de difusión a fin de interesar a sectores empresarios y estudiar las presentaciones hechas por las empresas para incorporarse al régimen de promoción.

9 A la cabeza del MAE se ubicó la Unión Industrial de Santa Fe (UISF), acompañada por el Centro Comercial, Bolsa de Comercio, Cooperametal, Sociedad Rural, Sociedad de Hoteles y Bares, Asociación Argentina de Ingenieros, Asociación de Carreteras y otras entidades. La Gaceta, Santo Tomé, 14/10/1958, p. 1.

10 El Litoral, Santa Fe, 15/8/1959, p. 4.

11 El Litoral, Santa Fe, 26/8/1959, p. 4. 
Wanderer y DKW. ${ }^{12}$ En 1958, la empresa Daimler-Benz (propietaria de Mercedes-Benz), compró la totalidad de Auto Union continuando con la producción de modelos DKW. En esos momentos se produjo su llegada a Argentina.

El proyecto que iba tomando forma entre la DKW alemana y empresarios argentinos, bajo el nombre de IASFSA, fue autorizado por el PEN el 4 de noviembre de 1959 a través del decreto 14583. Allí se fijan algunas cuestiones relevantes para el posterior desarrollo de la empresa. El decreto autorizaba la inversión de 1 millón de dólares en maquinarias, equipos, herramientas, matrices y dispositivos desde Auto Union GmbH para instalar la fábrica de IASFSA, bajo las condiciones establecidas por las leyes 14780 y 14781. Por otra parte, exigía la constitución definitiva de IASFSA como entidad jurídica y la presentación de sus estatutos. También estipulaba que la firma debía presentar un convenio con DINFIA ${ }^{13}$ para la fabricación de los motores, o en su defecto los planes para la integración de su propia planta de motores. Por último, autorizaba la radicación de la planta industrial en Sauce Viejo, aunque hasta tanto finalizaran las obras podía funcionar en la ciudad de Santa Fe. Dentro del conjunto de empresas que ingresaron al marco regulatorio del decreto 3693/59, IASFSA se ubicó junto a SIAM Di Tella, IAFA, Isard, Metalmecánica, Dinborg y otras dentro del grupo de empresas de capital mixto (asociación de capitales extranjeros y nacionales), configurando una estrategia distinta a la de otras empresas filiales de automotrices extranjeras, que fueron subsidiarias de sus casas matrices. Teniendo en cuenta la dimensión del proyecto y los planes de producción presentados, SIAM fue la apuesta de capital mixto más importante dentro del sector. ${ }^{14}$ IASFSA, con características bien diferentes, se ubicó en segundo lugar.

IASFSA cumplió con las exigencias del decreto 14583/59, constituyéndose como sociedad anónima e inscribiéndose en el Registro Público de Comercio de Santa Fe, el 10 de noviembre de 1959. Hasta que la planta de Sauce Viejo se construyese, el gobierno provincial cedió las instalaciones del Garage Oficial para alojar provisoriamente la fábrica. Por otra parte, la empresa firmó un convenio con DINFIA para la fabricación de motores. Ese acuerdo no se llevó a la práctica, no obstante el trabajo de la empresa estatal fue muy importante durante los primeros años de IASFSA en cuanto al montaje del motor y la caja de velocidades de los vehículos. ${ }^{15}$

12 DKW había sido fundada en 1916 con el nombre de Dampf-Kraft-Wagen, y se especializó inicialmente en la fabricación de motocicletas. Pasadas la década del '30 y la Segunda Guerra Mundial, Auto Union se relanzó en Alemania Occidental en 1949, con DKW como su marca más fuerte.

13 DINFIA (Dirección Nacional de Fábricas e Investigaciones Aeronáuticas) era la denominación que había tomado la empresa estatal IAME a partir de 1956.

$14 \mathrm{Al}$ respecto de SIAM Di Tella y su producción de automotores asociada a la British Motors Corporation, ROUGIER, Marcelo y SCHVARZER, Jorge, Las grandes empresas no mueren de pie. El (o) caso de SIAM, Norma, Buenos Aires, 2006.

15 El acuerdo entre DINFIA e IASFSA establecía la creación de una nueva sociedad anónima para 
La empresa se denominó "Industria Automotriz Santa Fe S.A. - Fábrica argentina de vehículos DKW Auto Union" y fijó su capital social en 250 millones de pesos $\mathrm{m} \$ \mathrm{n} .{ }^{16}$ No obstante, decidió rápidamente modificar sus estatutos y aumentar su capital a 600 millones de pesos $\mathrm{m} \$ \mathrm{n}$, decisión que fue aprobada por el gobierno provincial (decreto 13944/59, 11 de diciembre). El capital fue dividido en 60 series de 10000 acciones de $\$ 100$ pesos $\mathrm{m} \$ \mathrm{n}$ cada una. Del total de 600000 acciones, 500000 se constituyeron como acciones ordinarias con derecho a un voto ("acciones clase B"), mientras que las restantes 100000 se fijaron también como ordinarias pero con derecho a cinco votos ("acciones clase A"). El Directorio quedó conformado por siete miembros de Buenos Aires (Roberto Huerta como presidente, Federico De Bucourt como vicepresidente, Carlos Canobbio, Arnaldo Nasute, Argentino Castro, Pedro Daverda y Marcelo Louton como directores), tres de Santa Fe (Enrique Ariotti, Francisco Cordara y Carlos Mai) y un representante de la firma Mercedes-Benzque a su vez fue el delegado de DKW en Santa Fe (Federico Binder). Respecto a la procedencia de los integrantes del Directorio, los integrantes santafesinos estaban vinculados al MAE. ${ }^{17}$ Entre los que provenían de Buenos Aires, algunos habían pasado por las Fuerzas Armadas,$^{18}$ mientras que otros tenían experiencia previa en la fabricación de automotores. ${ }^{19}$

la producción de motores, controlada por ambas empresas. DINFIA ya contaba con un antecedente de índole similar, ya que en 1958 se había asociado a la firma Borgward Argentina para fabricar camiones y automóviles de la marca Dinborg. La sociedad anónima proyectada entre DINFIA e IASFSA no se realizó, y en la práctica DINFIA llevó a cabo los trabajos de montaje del motor y la caja de velocidades de los modelos Auto Union hasta 1963 cuando IASFSA pudo realizarlos en su propia planta. A partir de allí, DINFIA pasó a ser una importante proveedora de partes del motor. El texto del convenio entre DINFIA e IASFSA se encuentra en DINFIA, Libros de Actas de Directorio, Acta 123, 1/2/1960.

16 Registro Público de Comercio de la Primera Circunscripción Judicial de la Provincia de Santa $\mathrm{Fe}, \mathrm{N}^{\circ}$ XVII, pp. 906 a 926 del legajo, 10/11/1959. El valor del capital aprobado es en pesos moneda nacional.

17 Ariotti era dueño de la empresa Fundición Santa Fe, había estado en el directorio de la UISF, integraba para 1959 la Bolsa de Comercio de Santa Fe, y era el representante de dicha entidad en el IFI; además había sido miembro de la Junta Consultiva Nacional, y luego convencional constituyente por el partido Unión Federal. Cordara era desde 1957 el presidente de la UISF, mientras que Mai integraba la conducción del Banco de Crédito Comercial.

18 Castro y Huerta eran ingenieros aeronáuticos y habían sido Administradores Generales de la Fábrica Militar de Aviones (FMA) durante la "Revolución Libertadora". Castro desempeñó el cargo entre el 29/10 y el 18/11 de 1955. Huerta entre el 26/6/56 y el 1/5/58. Este último, con la asunción de Frondizi pasó a ser Ministro y luego Secretario de Aeronáutica hasta septiembre de 1958. Por el cargo que ambos ocuparon en la FMA, habían integrado el Directorio de IAME/DINFIA. Por su parte, Carlos Canobbio era Capitán de Corbeta (retirado).

19 De Bucourt y Daverda habían creado en la década del '40 la empresa TERAM, vinculada a la importación de automóviles Porsche y luego al desarrollo local del modelo Porsche Teram Puntero, que se hizo en base al modelo "Justicialista" desarrollado por IAME. De Nasute y Louton sólo co- 
La integración del capital social de IASFSA (335500 acciones, o sea 33,5 millones de $\mathrm{m} \$ \mathrm{n}$ ) muestra que la empresa DKW poseía el 73\% de las acciones ordinarias clase A; los socios locales que mayor participación tenían en acciones clase A eran Daverda y De Boucourt, seguidos de Louton y Nasute; los socios santafesinos integraban una minoritaria parte del capital; y los ex-miembros de las FF.AA. tan solo integraron 300 acciones clase B. Por otra parte, a partir de la ampliación del capital unos 9000 pequeños ahorristas compraron acciones clase B. ${ }^{20}$ Es probable que la rápida ampliación del capital decidida por la empresa en 1959 haya estado relacionada a dos factores. Por un lado, la intención de conseguir financiamiento recurriendo al ahorro interno canalizado a través de los pequeños accionistas, que por lo visto se mostraron muy interesados en el proyecto. Por otro, en el contexto de alta inflación y recesión económica de 1959, una inversión privada necesitaba actualizarse ante la devaluación del peso.

Además del capital integrado en acciones, como vimos anteriormente la inversión autorizada por el PEN a la firma DKW fue de un millón de dólares, a realizarse dentro de un plazo de 5 años. Sin embargo, en un trabajo del Consejo Nacional de Desarrollo (CONADE) se realiza una estimación de las inversiones reales hechas por las empresas automotrices, concluyendo que DKW había invertido solo el 46,4\% del total autorizado, es decir 464000 dólares. ${ }^{21}$ Acerca de las condiciones del acuerdo entre DKW y los inversionistas argentinos, una nota de El Litoral expone que "el contrato de la empresa argentina con Auto Union de Alemania, autoriza a que se utilicen las mismas marcas, patentes, usos, dispositivos y procedimientos industriales protegidos por la marca alemana. Por otra parte, IASFSA recibe de la empresa europea todo el asesoramiento técnico y facilidades para la formación profesional de su personal y se beneficia con los resultados de experimentación que en Alemania se incorporan a los nuevos modelos". ${ }^{22}$ Por otra parte, la empresa reconocía el asesoramiento del personal técnico proveniente de Alemania. ${ }^{23}$

La disímil procedencia de los integrantes del Directorio nos permite establecer algunas conexiones y esbozar otras. En primer lugar, el hecho de que un representante de MercedesBenz fuera delegado de la firma DKW en el Directorio se explica por la relación establecida entre las casas matrices de ambas empresas. Por otro lado, De Bucourt y Daverda (los socios argentinos de mayor peso en el capital social) se habían vinculado con DINFIA a partir de su empresa TERAM, y es probable que hayan sido los nexos locales con las empresas Wartburg

nocemos sus profesiones: el primero era industrial y el segundo, abogado.

20 Declaraciones del primer presidente del Directorio de IASFSA, Roberto Huerta. El Litoral, Santa $\mathrm{Fe}, 19 / 11 / 1960$.

21 CONSEJO NACIONAL DE DESARROLLO (CONADE), La industria automotriz: análisis preliminar, Buenos Aires, 1966; p. 54.

22 El Litoral, Santa Fe, 2/9/1961, p. 11

23 IASFSA, Memoria y Balance General al 30 de junio de 1963, 1963, s/n. 
y DKW en base a su experiencia previa en la importación de autos alemanes. Asimismo, el pasado de los militares Huerta y Castro dentro de la FMA y DINFIA seguramente sirvió de nexo entre IASFSA y algunos importantes actores políticos y empresariales. Por sus cargos al frente de la FMA, conocían muy bien el complejo industrial militar ubicado en Córdoba; en el caso de Huerta también podía establecer contactos con autoridades del gobierno nacional ya que había sido funcionario. Este importante rol "negociador" de Huerta y Castro parece confirmarse al notar la insignificante cantidad de acciones que ambos integraron en el capital social. Huerta se convirtió en el primer presidente del Directorio de IASFSA no justamente por ser un importante accionista local.

\begin{tabular}{|c|c|c|c|}
\hline \multicolumn{4}{|c|}{$\begin{array}{l}\text { Cuadro 1: Capital extranjero autorizado a radicarse en la industria } \\
\text { automotriz (en USS) }\end{array}$} \\
\hline Empresa & $1958 / 64$ & $1965 / 70$ & Total \\
\hline Citroën & 13.100 .000 & 1.104 .000 & 14.204 .000 \\
\hline Chrysler & 12.500 .000 & 5.637 .000 & 18.137 .000 \\
\hline General Motors & 19.800 .000 & & 19.800 .000 \\
\hline Mercedes-Benz & 6.600 .000 & & 6.600 .000 \\
\hline Fiat & 14.000 .000 & & 14.000 .000 \\
\hline IKA-Renault & 7.053 .000 & & 7.053 .000 \\
\hline Ford & 18.400 .000 & 8.800 .000 & 27.200 .000 \\
\hline IASFSA (DKW) & 1.000 .000 & & 1.000 .000 \\
\hline Peugeot & 4.500 .000 & & 4.500 .000 \\
\hline Goliath Hansa & 3.350 .000 & & 3.350 .000 \\
\hline Alcre (Heinkel) & 1.200 .000 & & 1.200 .000 \\
\hline Cisitalia & 628.000 & & 628.000 \\
\hline Siam Di Tella (British Motors) & 1.400 .000 & & 1.400 .000 \\
\hline $\begin{array}{c}\text { Total } \\
\end{array}$ & 113.531 .000 & 15.541 .000 & 129.072 .000 \\
\hline
\end{tabular}

En el Cuadro 1, aun considerando que son cifras de inversiones de capital extranjero autorizadas, es útil para observar dos cuestiones. En primer lugar, dentro del grupo de automotrices extranjeras que radicaron inversiones, el monto planificado por DKW fue uno de los más reducidos, y estuvo muy por debajo de los proyectados por empresas líderes del sector como Ford, Fiat o General Motors. En segundo lugar, se comprueba que luego de la inversión inicial, DKW no efectuó nuevas inversiones. El monto de su inversión demues- 
tra que estaba lejos de proponerse una relevante participación en el mercado argentino. ${ }^{24}$ No obstante eso, a diferencia de muchas otras empresas, IASFSA pudo mantenerse en el mercado hasta 1969.

\section{La producción de la empresa y su posición en el mercado nacional}

La rapidez que caracterizó al proceso de formación de IASFSA también se vio reflejada, ya entrado el año 1960, en el inicio de su producción. Con la llegada de material importado desde Alemania, el 3 de febrero se presentaron en la Casa de Gobierno de Santa Fe los primeros automóviles armados en la ciudad, realizándose un acto que contó con la presencia del Gobernador, miembros del gabinete, legisladores, jueces, militares, integrantes del directorio de IASFSA y del MAE. La presencia en el evento de figuras de todos los poderes del Estado provincial y la cobertura periodística realizada reflejan la jerarquía que tuvo este proyecto industrial para la ciudad de Santa Fe. El Litoral dedicó un editorial a elogiar el inicio de actividades por parte de IASFSA. ${ }^{25}$ En marzo, la empresa comenzó la construcción de su planta en Sauce Viejo. ${ }^{26}$ Por su ubicación geográfica, lejos de Buenos Aires y Córdoba donde la industria automotriz se encontraba más desarrollada y se contaba con algunas economías de escala, IASFSA constituyó una excepción dentro del grupo de terminales instaladas durante esos años. ${ }^{27}$ De los discursos pronunciados en la presentación oficial de primeros autos, puede concluirse que la decisión de instalar la planta industrial en Santa Fe se debió principalmente a la acción complementaria de cuatro actores: los inversores extranjeros, los inversores locales procedentes de Buenos Aires, el MAE, y el gobierno provincial.

Entre 1959 y 1969, el mercado automotriz local pasó de tener una conformación bastante particular a reproducir las tendencias del mercado mundial. En el plano de la oferta, luego de que el Estado nacional autorizara a fabricar a más de 20 empresas entre 1959 y 1961, fue cristalizando una tendencia hacia la conformación de un oligopolio. ${ }^{28}$ En el plano de la demanda, una reducida producción local sumada a volúmenes de importación irregulares

24 La producción de automotores es un rubro con intensiva utilización de capital, donde los altos costos en maquinaria y su renovación periódica requieren de grandes escalas de producción en pos de reducir costos de amortización. Los niveles de producción de las terminales en Argentina en la década del '60 se ubicaron muy lejos de los considerados óptimos a nivel internacional (BARANSON, Jack, La industria automotriz en..., Op. Cit.). Esta característica, que repercutía en los costos, era aún más notable en empresas de bajo volumen de producción como IASFSA.

25 El Litoral, Santa Fe, 4/2/1960, p. 4.

26 El Litoral, Santa Fe, 22/3/1960, p. 4.

27 SOURROUILLE, Juan, Transnacionales en..., Op. Cit., p. 55.

28 Ídem, p. 126. 
provocaron que la principal característica y atractivo del mercado fuese la importante demanda insatisfecha acumulada. ${ }^{29}$ La situación cambió con la entrada en vigencia del decreto $3693 / 59$, ya que junto al incremento de la oferta aumentaron significativamente las compras. En un escenario particular de alta demanda a comienzos de los 60, pudieron subsistir una gran cantidad de empresas, algunas de ellas con muy bajos volúmenes de producción.

Roberto Huerta había anunciado en más de una ocasión que IASFSA planificaba producir en sus primeros 5 años unas 22000-25000 unidades..$^{30}$ Finalmente IASFSA fabricó unos 17500 vehículos en 5 años, sobre una producción planificada en 20845 unidades. Considerando los problemas generados por la crisis de 1962-1963, que afectaron la producción de muchas automotrices, el cálculo de Huerta no estuvo muy alejado de la realidad. ${ }^{31}$ IASFSA tuvo un bajo volumen de producción para la industria automotriz, aunque suficiente para superar un período inicial (1959-1965) caracterizado por una depuración de capitales ${ }^{32}$ que dejó afuera del mercado a 13 empresas sobre las 26 autorizadas. La progresiva concentración de la oferta actuó a lo largo de toda la década del '60. El número de terminales bajó de 13 en 1965 a 9 en 1970. Sourrouille destacó que entre 1965 y 1969 los emprendimientos más importantes de capital mixto desaparecieron por distintas razones: IAFA entró en crisis y se convirtió en SAFRAR (controlada directamente por la casa matriz de Peugeot), Isard cerró, SIAM vendió su planta a IKA y finalmente IASFSA fue absorbida por Fiat. ${ }^{33}$ A diez años del decreto 3693/59, las filiales de las grandes automotrices mundiales controlaban prácticamente la totalidad del mercado argentino.

La oferta de modelos que presentó inicialmente IASFSA comprendía dos tipos de vehículos. ${ }^{34}$ Aquí deben tenerse en cuenta las reglas fijadas por el decreto 3693/59, y los segmentos

29 COSCIA, Santiago, Evolución, dinámica actual y perspectivas..., Op. Cit., s/n.

30 El Litoral, Santa Fe, 15/8/1959, p. 4; El Litoral, Santa Fe, 26/1/1960, p. 5; El Litoral, Santa Fe, 3/2/1960, p. 5.

31 La de 1962-63 fue una crisis característica del funcionamiento del modelo cíclico stop and go, generada a partir de un fuerte desequilibrio en el balance de pagos. Para Schvarzer, esta crisis fue producto de una sumatoria de factores relacionados a un manejo desaprensivo del sector externo por parte del gobierno nacional (SCHVARZER, Jorge, La industria que..., Op. Cit., pp. 236-237). Un análisis de la crisis y de las consecuencias que tuvo para el sector industrial se encuentra en BELINI, Claudio y ROUGIER, Marcelo, El Estado empresario en la industria argentina. Conformación y crisis, Manantial, Buenos Aires, 2008, capítulo 5.

32 IANNI, Valeria, "La especificidad del desarrollo...",Op. Cit.

33 SOURROUILLE, Juan, Transnacionales en..., Op. Cit., p. 58.

34 En este trabajo adoptamos una clasificación genérica de los vehículos propuesta por COSCIA, Santiago, Evolución, dinámica actual y perspectivas..., Op. Cit. Este autor separa a los automóviles de los comerciales. Entre los primeros encontramos a los llamados sedán y rurales. Dentro de los comerciales se ubican camiones, pick-ups, furgones, jeeps y vehículos de transporte colectivo de pasajeros (ómnibus, micro-ómnibus, etc.). 
de mercado que se formaron a partir de las categorías establecidas. La firma presentó un vehículo comercial o utilitario llamado "Frontal", que se ubicó dentro de la categoría A (chasis para vehículo de carga y transporte colectivo, con capacidad de carga útil mínima de $500 \mathrm{~kg}$. y máxima de 7000) con varios modelos de carrocería; y dos modelos de automóviles, el "Auto Union 1000S" y el "Rural Auto Union Universal", que por el tamaño de su motor se ubicaron en la categoría C (vehículos de pasajeros con cilindrada de más de 750 $\mathrm{cm}^{3}$, y hasta $1500 \mathrm{~cm}^{3}$ ) correspondiente al segmento de automóviles medianos. Luego, en 1963, la empresa agregó a su oferta un modelo de automóvil de tipo deportivo: el "Fissore".

La oferta planificada por IASFSA en 1960 tenía características similares a las que lanzaron otras automotrices, en cuanto a la importancia dada al desarrollo de los comerciales (categoría A) en comparación con los automóviles. Los mayores beneficios que estableció el marco normativo para la producción de comerciales impulsaron a muchas empresas a buscar réditos en ese segmento. Cabe destacar que en 1959 las grandes automotrices (Ford, General Motors y Chrysler) tomaron la decisión de fabricar en el país solamente camiones y pick-ups, y recién a partir del decreto 6567/61 incorporaron automóviles a su oferta. ${ }^{35}$ El comportamiento de la demanda en el mercado local a comienzos de la década del ' 60 generó un mayor dinamismo de los automóviles en comparación a los comerciales. A su vez, dentro de los automóviles surgió una tendencia favorable al consumo de los modelos de mayor peso y valor. ${ }^{36}$ En el caso de IASFSA, observamos el cambio de orientación en su producción, entre los planes iniciales (presentados ante la Secretaría de Industria por el plazo de 5 años) y los planes definitivos (aprobados por dicha Secretaría año tras año): el porcentaje de comerciales sobre la producción total se redujo del 39\% inicial al 18\% definitivo, incrementándose el de automóviles desde el 61\% al 82\%. ${ }^{37}$ En su Memoria de 1962, la empresa explicaba el porqué del cambio de orientación: la venta del Frontal era menos fluida en relación a los demás modelos, y además las autoridades nacionales demandaban a las automotrices un mayor ahorro de divisas. ${ }^{38}$ En este punto, puede concluirse que IASFSA buscó capitalizar (al igual que otras empresas del sector) los mayores beneficios brindados por la legislación al segmento de vehículos comerciales, pero al poco tiempo realizó (también como otras empresas) una adaptación al mayor dinamismo de la demanda de automóviles.

En el Cuadro 2 puede observarse la evolución de la producción de todos los modelos de IASFSA. Allí puede verse la lentitud en el establecimiento de la oferta completa de modelos,

35 SOURROUILLE, Juan, Transnacionales en..., Op. Cit.; CONADE, La industria automotriz..., Op. Cit.

36 CONADE, Ídem, pp. 11-12.

37 Sobre los planes iniciales, ver Revista El Automóvil Argentino, ACARA, No VIII, Buenos Aires, 1961, p. 37. Los planes definitivos se encuentran en Ídem, p. 59.

38 IASFSA, Memoria y Balance General al 30 de junio de 1962, 1962, s/n. Cabe suponer que el pedido de las autoridades nacionales estaba motivado por la emergencia de la crisis en 1962. 
ya que a pesar de los anuncios realizados, en 1960 y 1961 la producción prácticamente se redujo a un único modelo: el 1000S. También se destaca la centralidad que tiene el 1000S en la producción total; sin dudas fue el modelo más exitoso. Además, el desarrollo del Frontal perdió importancia tan solo un año después de su lanzamiento. La reorientación productiva resultante benefició al desarrollo del modelo Rural Universal, que hasta 1965 representó una parte considerable de la producción. Por último, puede afirmarse que el Fissore fue un intento de ingresar al segmento de automóviles deportivos que no funcionó.

\begin{tabular}{|l|r|r|r|r|r|r|r|r|r|r|r|}
\hline \multicolumn{10}{|c|}{ Cuadro 2: Producción de IASFSA } \\
\cline { 2 - 14 } & \multicolumn{10}{|c|}{$\mathbf{1 9}$} \\
\hline Modelo & $\mathbf{1 9 6 0}$ & $\mathbf{1 9 6 1}$ & $\mathbf{1 9 6 2}$ & $\mathbf{1 9 6 3}$ & $\mathbf{1 9 6 4}$ & $\mathbf{1 9 6 5}$ & $\mathbf{1 9 6 6}$ & $\mathbf{1 9 6 7}$ & $\mathbf{1 9 6 8}$ & $\mathbf{1 9 6 9}$ & Total \\
\hline Auto Union 1000S & 904 & 1800 & $\underline{2475}$ & $\underline{1925}$ & 3350 & 3686 & 3978 & 2182 & 865 & 632 & 21797 \\
\hline Auto Union 1000SF (Fissore) & & & & 280 & 288 & 132 & & & & & 700 \\
\hline Rural Universal & & 150 & $\underline{1000}$ & $\underline{732}$ & 1440 & 1512 & 657 & 568 & 193 & 144 & 6396 \\
\hline Total automóviles & 904 & 1950 & 3475 & 2937 & 5078 & 5330 & 4635 & 2750 & 1058 & 776 & 28893 \\
\hline Frontal & & 1100 & 600 & 500 & 942 & 164 & 100 & 69 & 35 & 225 & 3735 \\
\hline \multicolumn{1}{|c|}{ Total de la empresa } & 904 & 3050 & 4075 & 3437 & 6020 & 5494 & 4735 & 2819 & 1093 & 1001 & 32628 \\
\hline
\end{tabular}

Elaboración propia en base a: ADEFA (Anuarios de 1969 y 1970), CONADE (1966) y Baranson (1971). Las cantidades subrayadas son cifras aproximadas.

Cuadro 3: Participación de IASFSA en el mercado nacional de automóviles y automotores

\begin{tabular}{|c|c|c|c|c|c|c|c|c|c|c|}
\hline & 1960 & 1961 & 1962 & 1963 & 1964 & 1965 & 1966 & 1967 & 1968 & 1969 \\
\hline IASFSA - producción automóviles (unid.) & 904 & 1.950 & 3.475 & 2.937 & 5.078 & 5.330 & 4.635 & 2.750 & 1.058 & 776 \\
\hline IASFSA - producción total (unid.) & 904 & 3.050 & 4.075 & 3.437 & 6.020 & 5.494 & 4.735 & 2.819 & 1.093 & 1.001 \\
\hline Producción nacional - total automóviles (unid.) & 30.335 & 71.993 & 78.667 & 68.111 & 104.459 & 119.782 & 123.937 & 124.587 & 120.224 & 147.512 \\
\hline Producción nacional - total automotores (unid.) & 89.338 & 136.188 & 129.880 & 104.899 & 166.483 & 194.536 & 179.453 & 175.318 & 180.976 & 218.590 \\
\hline Participación de IASFSA en automóviles (\%) & 2,98 & 2,71 & 4,42 & 4,31 & 4,86 & 4,45 & 3,74 & 2,21 & 0,88 & 0,53 \\
\hline Participacion de IASFSA en automotores (\%) & 1,01 & 2,24 & 3,14 & 3,28 & 3,62 & 2,82 & 2,64 & 1,61 & 0,60 & 0,46 \\
\hline IASFSA - variación interanual de producción (\%) & & 237,39 & 33,61 & $-15,66$ & 75,15 & $-8,74$ & $-13,82$ & $-40,46$ & $-61,23$ & $-8,42$ \\
\hline Producción nacional - variación interanual (\%) & & 137,33 & 9,27 & $-13,42$ & 53,37 & 14,67 & 3,47 & 0,52 & $-3,50$ & 22,70 \\
\hline
\end{tabular}

Fuente: elaboración propia en base a datos de ADEFA, Industria automotriz argentina, Buenos Aires, 1972, s/n

Si comparamos la producción de IASFSA con el conjunto de la rama automotriz, es evidente que su participación en el mercado fue marginal. El Cuadro 3 muestra que la producción de IASFSA nunca representó más del $4 \%$ de la producción nacional. En lo que respecta a automóviles, su participación fue ligeramente superior, ubicándose cerca del 5\%. A pesar de su ubicación en el mercado, en octubre de 1964 IASFSA se incorporó a la Asociación de Fábricas de Automotores (ADEFA) ${ }^{39}$. No obstante las cifras de producción,

39 ADEFA agrupa a las empresas fabricantes de automotores. Fue creada en 1961 y estuvo conformada inicialmente por siete firmas: Févre y Basset-Chrysler; Fiat; Ford; General Motors; Industrias Kaiser; Mercedes-Benz y SIAM Di Tella Automotores. IASFSA fue la octava empresa en integrarse a la asociación. 
podemos afirmar que el modelo $1000 \mathrm{~S}$ se consolidó exitosamente en el mercado. La empresa reconocía en sus memorias anuales el suceso de dicho modelo: en 1962 y 1964 afirmaba que su producción no alcanzaba a cubrir la demanda ${ }^{40}$ Los testimonios de obreros y empleados que trabajaron en IASFSA coinciden en señalar que la empresa trabajaba con un stock muy reducido de unidades terminadas. ${ }^{41} \mathrm{Al}$ parecer, las razones del éxito del $1000 \mathrm{~S}$ se encuentran en sus características técnicas y su elogiada performance. ${ }^{42}$

El 1000S se afianzó dentro de un segmento del mercado en el cual prácticamente no se interesaron las empresas líderes, y donde se fue convirtiendo en el único modelo de su clase. ${ }^{43}$ Por su motor de $980 \mathrm{~cm}^{3}$, quedaba fuera del segmento de automóviles pequeños (hasta 800 $\mathrm{cm}^{3}$ ), hacia el cual habían apuntado varias empresas de capital nacional y otras extranjeras como Fiat, IKA-Renault y Citroën. A su vez, estaba muy lejos de las características de los automóviles grandes (con motores de más de $2000 \mathrm{~cm}^{3}$ ), segmento donde se hacían fuertes las empresas de origen norteamericano: Ford, IKA, General Motors y Chrysler. En un estudio que realizó ADEFA a finales de la década del ' 60 , la clasificación de los automóviles en cuatro segmentos arrojó como conclusión que sólo el 5,8\% de los fabricados entre 1959 y 1968 pertenecieron al segmento cuyo motor tenía de 851 a $1400 \mathrm{~cm}^{3}$ de cilindrada. ${ }^{44}$ Es

40 En 1962, la empresa afirmaba que "en lo que respecta a la comercialización de sus productos, la Empresa puede mostrarse satisfecha de la misma. El modelo Sedan 4 puertas sigue teniendo una extraordinaria aceptación y todavía su producción no cubre la demanda" (IASFSA, Memoria y Balance General al 30 de junio de 1962, 1962, s/n.). Y en 1964, "La producción ha experimentado un aumento en el ejercicio y su comercialización, no ha tenido dificultades, siendo por el contrario, superior la demanda a la producción" (IASFSA, Memoria y Balance General al 30 de junio de 1964, 1964, s/n.).

41 Un ex empleado administrativo manifestó que en algunos momentos los clientes esperaban la entrega de su auto en las afueras de la planta, mientras el coche se terminaba de fabricar (Hugo R., entrevista del autor, realizada el 2/3/2011). Otro trabajador entrevistado señala que "el auto se vendía bien. Lo que pasa es que había una gran limitación en la producción" (Rodolfo B., entrevista del autor, realizada el 11/3/2011).

42 La revista Parabrisas, Buenos Aires, 1962, № XVII, concluye su evaluación del 1000S diciendo que es "un señor auto", ya que "para andar en el tránsito, la tercera velocidad es de una elasticidad y reacción que incita a usarla casi continuamente; y la rueda libre es una gran comodidad. El espacio interior es amplísimo dentro de esa categoría; la suavidad y la serenidad de marcha son notables. Amplio, económico y 'roscador', el Auto Unión puede ser la solución para muchos". Cabe mencionar que la mayoría de los ex trabajadores entrevistados coincidió en calificar positivamente la calidad del 1000S, no así la de los demás modelos.

43 A diferencia de IASFSA, la empresa SIAM que a comienzos de la década del ' 60 prácticamente no tenía competidores para su modelo Morris 1500, luego perdió el liderazgo del segmento a manos de Fiat y su modelo 1500 .

44 Mientras que el 35,5\% correspondía a los de motores de más de $2500 \mathrm{~cm}^{3}$ de cilindrada, el $34,9 \%$ hasta $850 \mathrm{~cm}^{3}$ y el 23,8\% de 1401 a $2500 \mathrm{~cm}^{3}$ (ADEFA, Industria automotriz argentina, Buenos Aires, 1969, p. 3.). 
entonces en el más reducido de todos los segmentos, el de los medianos chicos, donde IASFSA consiguió afianzar su modelo 1000S. Entre 1965 y 1969 fue prácticamente la única empresa que fabricó automóviles con motores de entre 800 y $1400 \mathrm{~cm}^{3}$ de cilindrada.

\section{Algunas características de su organización interna}

La empresa comenzó teniendo dos sedes: una en Buenos Aires, donde se ubicó la mayor parte de su administración, y otra en Santa Fe, donde se armaban los automotores. Con la entrada en funcionamiento de la planta de Sauce Viejo, una parte considerable de las actividades se fue trasladando hacia allí. ${ }^{45}$ Esta planta contaba con $30000 \mathrm{~m}^{2}$ cubiertos, y su construcción demandó un año y medio.

La cantidad de obreros y administrativos que trabajaban en la empresa era de 300 en 1960, pasó a 1020 en 1961 y llegó a 1500 en 1965. Una particularidad de la empresa fue que sus trabajadores se encuadraron sindicalmente en la Unión Obrera Metalúrgica (UOM), y no en el Sindicato de Mecánicos y Afines del Transporte Automotor (SMATA). ${ }^{46}$ Acerca de los empleos directos generados por la fábrica, es importante resaltar que según las estadísticas recopiladas por el Gobierno santafesino, el promedio de personal ocupado por establecimiento fabril en el Departamento La Capital (donde se radicó IASFSA) era de 5,6 personas para el sector Metales y de 14,1 para el sector Vehículos y Maquinaria. ${ }^{47}$ Este dato ilustra la gran dimensión que tuvo IASFSA dentro de una región (el centro de la provincia) que carecía de grandes industrias. El CONADE destacaba años después que las inversiones de IASFSA fueron "muy significativas en relación con el grado de desarrollo industrial de la zona". ${ }^{48}$

Las características de los procesos de trabajo dentro de la fábrica coinciden a grandes rasgos con lo señalado por estudios realizados a nivel nacional. Desde distintas perspec-

45 El organigrama de la empresa muestra que el Directorio y las gerencias Comercial y de Relaciones Públicas (además del síndico y los auditores externos) estaban localizados en Buenos Aires. En cambio, las gerencias Técnica y Administrativa, así como la totalidad de los departamentos dependientes de ellas (Compras, Finanzas, Producción, Relaciones industriales, Ingeniería, Control de calidad, etc.) se ubicaron en Sauce Viejo. Con el reemplazo de Huerta por Ariotti en la presidencia del Directorio hacia 1963, las actividades del mismo pasaron a dividirse entre Santa Fe y Buenos Aires.

46 Este hecho tuvo importantes consecuencias sobre las características de la relación capital-trabajo establecida en IASFSA. Al respecto, VICENTIN, Enzo, "La primera experiencia de los trabajadores automotrices en Santa Fe. Acción sindical y relación capital-trabajo en el caso de la empresa IASFSA (1959-1969)", ponencia presentada en el V Congreso Regional de Historia e Historiografía, Universidad Nacional del Litoral, Santa Fe, 2013.

47 Dirección General de Estadística y Censos, Censo industrial de 1960, , Ministerio de Hacienda, Economía e Industrias, Provincia de Santa Fe, 1962, Boletín № 9.

48 CONADE, La industria automotriz..., Op. Cit., p. 26. 
tivas teóricas, se coincide en que el componente subjetivo dado por la mano de obra fue un factor fundamental en la rama automotriz de la época. ${ }^{49}$ Un obrero que trabajó en el sector de ingeniería de procesos afirmó que "en la línea era todo manual, no había nada de alimentación automática, hubo mucha mano de obra", y otro que fue jefe de planta remarcó que en general "había mucha artesanía en el terminado de la carrocería". ${ }^{50}$ No obstante, esta característica se convertía en un serio problema cuando ni siquiera se contaba con el instrumental básico para sostener los requerimientos de la producción. Tal fue el caso del modelo Fissore. ${ }^{11}$ Sin embargo, este ejemplo no contradice el hecho de que la empresa haya introducido algunos procesos de trabajo y tecnologías (industriales y administrativas) prácticamente desconocidas hasta ese momento en la región central de Santa Fe.

El crecimiento de la planta fabril no solo estuvo relacionado a la mayor dimensión que iba adquiriendo la empresa, también estuvo relacionado al proceso de integración nacional de los vehículos. Considerando las pautas fijadas por el decreto 3693/59, la empresa avanzó gradualmente en la elaboración propia de procesos y componentes complejos. Justamente, el armado integral y montaje del motor y la caja de velocidades (en 1963), y el estampado de la carrocería (en 1964) fueron los procesos que más tiempo le llevó incorporar. Entre la producción en su propia planta y la compra de partes y piezas a empresas nacionales, la integración nacional de los modelos Auto Union fue creciendo año a año. ${ }^{52} \mathrm{La}$ empresa expresaba en sus memorias anuales su satisfacción por cumplir con las disposiciones oficiales sobre planes de inversión y producción y la integración nacional de sus modelos. Sin embargo, esto se verá cuestionado en 1966 por la Dirección Nacional de Aduanas (DNA).

49 Como lo describe Brennan para las automotrices radicadas en Córdoba, "los trabajadores realizaban cientos de operaciones de mandrilado, rectificado, taladrado, enroscado y fresado. [En las plantas de Fiat e IKA-Renault] se realizaba una cantidad desacostumbradamente alta de tareas informales y no automatizadas" en BRENNAN, James, El Cordobazo, Sudamericana, Buenos Aires, 1996, p. 125. Estas características del trabajo hacían "que la calidad final dependiera de la fuerza de trabajo especializada en lugar de quedar garantizada por el propio proceso automático o mecanizado" (IANNI, Valeria, "La especificidad del desarrollo...", Op. Cit., p. 108). La destreza manual estaba relacionada, sin dudas, a las características tecnológicas de la maquinaria con que se operaba.

50 El primer testimonio pertenece a Rodolfo B. (entrevista del autor, realizada el 11/3/2011). El segundo a Carlos G. (entrevista del autor, realizada el 27/5/2011).

51 Este fue un modelo del que "se hicieron algunos pocos vehículos pero se desarmó todo a los pocos meses porque era un masacote de piezas moldeadas a mano"; la empresa "no tenía matricería para hacerlo y entonces hacían los modelos de madera y a golpecitos de martillo iban hundiendo la chapa". Testimonios de Rodolfo B. y Carlos G., respectivamente.

52 En su primer año de producción, la empresa calculaba que el porcentaje nacional de sus vehículos era del $42 \%$. Un año más tarde, alcanzaba el $55 \%$, y se proyectaba alcanzar el $65 \%$ en 1962 , el $75 \%$ en 1963 y un $90 \%$ en 1964. Los datos provienen de El Litoral, Santa Fe, 22/10/1960, p. 5 y El Litoral, Santa Fe, 2/9/1961, 2a sección, p. 6. 
El aumento de la producción y su mayor integración nacional, generaron un crecimiento en el intercambio comercial que la empresa tenía con otros subsectores de la rama automotriz..$^{53}$ Para 1967, el número de proveedores era mayor a 1000, de los cuales alrededor de 500 estaban situados en la provincia de Santa Fe ${ }^{54}$ Además, había 110 concesionarios y 28 talleres especializados en todo el país. En la provincia de Santa Fe se encontraban 10 concesionarios y 11 talleres. ${ }^{55}$ Sumando sus empleos directos al impacto sobre subsectores asociados, podemos afirmar que el efecto multiplicador que tuvo IASFSA en la economía de la región fue muy importante. Observando las estadísticas provinciales, resulta evidente que el crecimiento del sector industrial "vehículos y maquinaria" estuvo en gran parte relacionado a la instalación de grandes empresas como IASFSA. El número de establecimientos de dicho sector aumentó de 3408 en 1960 a 6734 en el año 1964 (97\%). Además el sector del caucho, vinculado a la rama automotriz, también experimentó un crecimiento notable entre esos años: de 77 establecimientos pasó a $294 .{ }^{56}$

\section{La evolución económico-financiera}

Considerando las características de IASFSA ya observadas, ahora cabe preguntarnos por su evolución económico-financiera, y particularmente por el recorrido de sus ventas y utilidades. Considerando diferentes razones, dos investigadores ${ }^{57}$ coinciden en que la rentabilidad de las automotrices en el país fue alta en los primeros años (1959-1961) y luego fue reduciéndose con el paso del tiempo. Relacionando estos aportes con la trayectoria de IASFSA, observamos que en esta empresa parece confirmarse el declive de rentabilidad, aunque esa caída fue bastante más aguda.

En el Cuadro 4 se observan las ventas y utilidades anuales de la empresa, así como también su ubicación dentro de las cien principales empresas industriales del país. ${ }^{58} \mathrm{~A}$ partir de los datos pueden identificarse tres etapas. Los años 1960 y 1961 constituyen la etapa más positiva de la empresa, al punto que allí se produjo el único pago de dividendos sobre

53 En un informe hecho por inspectores de la Secretaría de Industria a partir de visitar la planta de IASFSA en 1963, figuran como proveedoras de partes o piezas más de 20 empresas nacionales, entre ellas DINFIA.

54 Revista Tiempo, Santa Fe, 1967, No XIV, p. 17.

55 Ibídem.

56 VÁZQUEZ, Eladio, Política y acción industrial en la Provincia..., Op. Cit.

57 BARANSON, Jack, La industria automotriz en..., Op. Cit.; SOURROUILLE, Juan, Transnacionales en..., Op. Cit.

58 Los balances anuales de IASFSA se extendían de julio a junio del año siguiente. En las estadísticas, el año que figura corresponde al año de cierre del balance. Las cifras de 1960 abarcan tan sólo 5 meses. 
acciones de toda su trayectoria. ${ }^{59}$ Con la recesión de 1962 comenzó una segunda etapa, iniciada por una caída y seguida de una progresiva recuperación hasta 1965. Si bien el valor de las ventas creció año a año hasta 1965, esto se explica por el incremento en el volumen de producción (ver cuadro 2). La caída en las utilidades respecto a 1961 es un claro indicio de la complicada situación financiera que IASFSA atravesó en 1962-63. La recuperación se inició en 1964 y se consolidó en 1965, cuando la empresa salió de tres años consecutivos de pérdidas. Sin embargo, una tercera etapa comenzó en 1966 y marcó la crisis definitiva de la empresa. Por primera vez el valor de ventas cayó respecto al año anterior, y la situación financiera desmejoró hasta un nivel alarmante en 1967. Observando la posición de IASFSA dentro de las 100 empresas industriales más importantes de la época, se destaca el mejor desempeño que tuvo en las ventas respecto a las utilidades, un indicio de que IASFSA no tuvo problemas en la comercialización de sus productos sino en la situación interna de sus finanzas. En este punto puede trazarse un paralelismo con el caso de SIAM, donde su empresa de automotores tenía hacia 1965 problemas más financieros que productivos. ${ }^{60}$

\begin{tabular}{|l|r|r|r|r|r|r|r|r|}
\hline \multicolumn{1}{|c|}{ Cuadro 4: IASFSA: ventas, utilidades y posición dentro de las 100 mayores industrias del pais } \\
\cline { 2 - 10 } & $\mathbf{1 9 6 0}$ & \multicolumn{1}{|c|}{$\mathbf{1 9 6 1}$} & $\mathbf{1 9 6 2}$ & $\mathbf{1 9 6 3}$ & $\mathbf{1 9 6 4}$ & $\mathbf{1 9 6 5}$ & $\mathbf{1 9 6 6}$ & $\mathbf{1 9 6 7}$ \\
\hline Ventas (1) & 41 & 467 & 683 & $\mathbf{9 0 2}$ & 1196 & 1502 & 1497 & 1330 \\
\hline Utilidades (1) & 3 & 69 & 3 & -49 & -36 & 15 & -27 & -118 \\
\hline Utilidades sobre ventas (\%) & 7 & 15 & 0,4 & 0 & 0 & 1 & 0 & 0 \\
\hline Puesto en el ranking de ventas (2) & & & 84 & 61 & 53 & 56 & 67 & 96 \\
\hline Puesto en el ranking de utilidades (2) & & & 88 & 90 & 93 & 83 & 93 & 92 \\
\hline
\end{tabular}

Fuente: Elaboración propia en base a Revista Panorama de la Economía Argentina, varios números. De 1968 en adelante, no se dispone de información. (1) En millones de mSn de 1960

(2) Basado en: "Las 100 empresas industriales que tuvieron mayores ventas", Revista Panorama de la Economía Argentina, varios números. La estadistica incluye a empresas de todos los sectores manufactureros.

No obstante, la postura de la empresa acerca de su situación financiera fue enfatizar las influencias negativas de los problemas macroeconómicos nacionales. Así se desprende de las memorias de 1962 y 1963, donde el Directorio se queja por los efectos de la desvalorización de la moneda, ya que impactaba sobre las importaciones pero también sobre un conjunto de factores (gastos financieros, precios de materiales nacionales, remuneraciones salariales) que sumados elevaban los costos de producción. ${ }^{61}$ En cuanto al financiamiento

59 La empresa pagó a los propietarios de sus acciones dividendos del $20 \%$ en acciones ordinarias clase B, a partir del ejercicio cerrado en junio de 1961. Revista de la Bolsa de Comercio de Rosario, 1962, p. 23, $\mathrm{N}^{\mathrm{o}}$ MCCIX.

60 ROUGIER, Marcelo y SCHVARZER, Jorge, Las grandes empresas no..., Op. Cit., p. 35, argumentan que SIAM no disponía para esa época de financiamiento para invertir en la fabricación de nuevos modelos, ni para financiar sus ventas en condiciones competitivas respecto a las grandes firmas automotrices.

61 IASFSA, Memoria y Balance General al 30 de junio de 1962, 1962, s/n; IASFSA, Memoria 
de la empresa, anteriormente vimos que la ampliación de capital decidida en un comienzo fue un modo de financiarse a través del aporte de pequeños ahorristas. Esta intención se vio continuada con la decisión de cotizar acciones en la Bolsa de Comercio. Asimismo, IASFSA no recurrió al crédito bancario para su financiamiento, algo que se debía a las dificultades para obtener créditos, ${ }^{62}$ y tampoco recurrió al financiamiento externo. Esto puede corroborarse observando sus balances anuales, ya que dentro del pasivo las deudas comerciales siempre fueron mayores que las bancarias. Volviendo a las apreciaciones del Directorio, en 1964 el balance arroja pérdidas, ante lo cual las soluciones deben buscarse al interior de la empresa, en "una cuidadosa política financiera y una mayor racionalización de métodos y sistemas de producción". ${ }^{63}$ La recuperación registrada en 1965 fue un "resultado favorable reflejo de la labor cumplida en orden a una mejor organización administrativa orientada hacia la consecución de mayores beneficios a través de un más estricto control operacional". ${ }^{64}$ Sin embargo, la situación económica, que no era buena antes de 1966, empeorará para la empresa a partir de los problemas que se derivaron de la suspensión para ingresar importaciones, decidida por la DNA. Dicho incidente abrió una etapa muy crítica de la empresa, que finalmente desembocó en la venta de su planta industrial a Fiat en 1969.

\section{La crisis definitiva}

Aunque su producción de automotores se extienda hasta 1969, puede afirmarse que la actividad de la empresa se encontraba con serios problemas desde 1967, y prácticamente paralizada desde 1968. A las dificultades macroeconómicos (devaluación de la moneda e inflación) y estructurales de la empresa (bajo volumen de producción y falta de financiamiento para nuevas inversiones) se le sumaron los problemas con la DNA. En 1966, este organismo abrió una investigación contra IASFSA, indagando en sus operaciones de importación realizadas a través de despachantes particulares durante los años 1965 y 1966. La DNA comprobó que algunos certificados de abastecimiento para la empresa se habían falsificado, y en otros se habían adulterado los recargos establecidos (cambiando el 300\% que correspondía por el 40\%, como si fuese recargo promocional). En enero de 1967 la DNA

y Balance General al 30 de junio de 1963, 1963, s/n. La empresa SIAM se expresa para la misma época en términos coincidentes, señalando el impacto negativo de las dificultades macroeconómicas del país. ROUGIER, Marcelo y SCHVARZER, Jorge, Las grandes empresas no... Op. Cit., p. 41.

62 Un trabajador que ocupó un puesto importante en la administración señaló que "yo recuerdo haber ido muchas veces al Banco Provincial de Santa Fe, pero no teníamos líneas de créditos ahí. Se trabajaba con todos los bancos. Mucho crédito no teníamos, pero se hacían descuentos de documentos" (José M., entrevista del autor, realizada el 3/3/2011).

63 IASFSA, Memoria y Balance General al 30 de junio de 1964, 1964, s/n.

64 IASFSA, Memoria y Balance General al 30 de junio de 1965, 1965, s/n 
acusó a IASFSA ante la Justicia federal por contrabando en forma reiterada. El juicio se extendió increíblemente hasta 1996, cuando se resolvieron las absoluciones de los últimos imputados. ${ }^{65}$ A raíz de la investigación de la DNA, la Secretaría de Industria auditó las operaciones de importación de la empresa, encontrando irregularidades en los registros de 1962, 1963 y 1964, e imponiendo a partir de ello una fuerte multa sobre IASFSA. ${ }^{66}$

Dentro de un marco legal con amplios beneficios para las inversiones extranjeras (ley 14780), y en particular para las automotrices (decreto 3693/59), la regulación estatal no alcanzaba a evitar las maniobras empresarias que buscaban eludir el cumplimiento de algunas exigencias. ${ }^{67}$ Por lo tanto, no fueron infrecuentes los casos en los cuales la Secretaría de Industria detectó a posteriori prácticas dudosas de parte de las automotrices. Los problemas que en distintos momentos tuvieron Cisitalia y Autoar, IAFA, Metalmecánica, y finalmente IASFSA en cuanto a la integración nacional de los vehículos fabricados es una muestra de ello. No casualmente las mencionadas fueron firmas de capital nacional o mixto, que tuvieron problemas de competitividad en un mercado crecientemente oligopólico. Aquí interpretamos que IASFSA apeló a la evasión de compromisos impositivos (al no pagar recargos aduaneros) como mecanismo "alternativo" de financiamiento. ${ }^{68}$

Las sanciones impuestas por la DNA impactaron fuertemente en el ritmo de producción y desenvolvimiento financiero de la empresa. Ésta expresaba en su memoria de 1966 que "la interdicción de retirar los materiales de importación provocó la reducción al mínimo de la producción que a su vez produjo como lógica consecuencia una marcada disminución de las ventas, lo que nos colocó en una crítica situación financiera". ${ }^{69}$ Ante la gravedad del escenario, uno de los mecanismos que utilizó IASFSA para financiar sus operaciones fue la venta de certificados de producción de automóviles, práctica que tuvo pésimos resultados. ${ }^{70} \mathrm{El}$ agravamiento de los problemas no solamente afectó la posibilidad de afrontar

65 Las fuentes de información obtenidas sobre este tema fueron facilitadas por un entrevistado.

66 El Litoral, Santa Fe, 19/3/1969, p. 5

67 Al respecto de la escasa o nula capacidad regulatoria del Estado nacional durante el desarrollismo, SCHVARZER, Jorge, La industria que supimos..., Op. Cit.

68 En el caso de SIAM Di Tella, si bien no tuvo problemas por la integración nacional de sus vehículos, también recurrió a la evasión fiscal como estrategia de financiamiento. ROUGIER, Marcelo y SCHVARZER, Jorge, Las grandes empresas no..., Op. Cit. Al respecto de la acumulación de deudas fiscales como mecanismo de financiamiento, ALTIMIR, Oscar, SANTAMARÍA, Horacio y SOURROUILLE, Juan, "Los instrumentos de promoción industrial en la postguerra", en Desarrollo Económico, , IDES, Buenos Aires, 1966/67, ํo 21, V. 6 a Nº 27, V. 7.

69 IASFSA, Memoria y Balance General al 30 de junio de 1966, 1966, s/n.

70 Según un ex empleado, esa práctica provocaba muchísimos inconvenientes, porque "un auto tenía un respaldo que era un certificado de producción, verde, donde estaban los detalles, numero de motor, chasis... tenía que andar la gente de producción diciendo 'ojo mirá que este motor numero tal tiene que ir con este chasis numero tal'. Un lío tremendo. Vendían autos que no estaban hechos, pero 
créditos comerciales, sino que posteriormente (en 1967 y 1968) provocó retrasos en el pago de salarios. Esta situación derivó en un escenario conflictivo con el personal, que incluyó paros, despidos y negociaciones entre las partes con la mediación del Estado santafesino. ${ }^{71}$ En ese contexto, organizaciones integrantes del MAE santafesino (que había impulsado la radicación de IASFSA) se posicionaron en defensa de la empresa. La UISF manifestaba en 1968 su compromiso con el mantenimiento de la fuente de trabajo ${ }^{72}$, en coincidencia con las preocupaciones de la política industrial hacia finales de la década del ' $60 .{ }^{73}$ Vale recordar que Cordara y Ariotti estaban vinculados a la UISF al mismo tiempo que integraban el Directorio de IASFSA.

Ante el deterioro económico, en 1968 el Directorio buscó soluciones a través de por lo menos tres medidas. En primer término, declaró la convocatoria de acreedores a fin de evitar la quiebra definitiva de IASFSA. Además, buscó ingresar a los beneficios pautados por la ley nacional 17507, destinada a prestar ayuda estatal a empresas con problemas financieros. ${ }^{74}$ IASFSA ingresó al régimen de "rehabilitación", pero no recibió ningún crédito del Banco Industrial ya que las ayudas económicas comenzaron a aplicarse en los últimos

vendían y entregaban el papel porque si no las concesionarias no le daban la plata. Cuando la fábrica cerró definitivamente había más de mil autos vendidos que faltaban producir" (Hugo R., entrevista del autor, realizada el 2/3/2011).

71 Acerca del tema, VICENTIN, Enzo, La primera experiencia de los trabajadores automotrices en Santa Fe..., Op. Cit.

72 "En estos difíciles momentos por lo que está atravesando la empresa, [la UISF] ha participado en gestiones de todo orden ante autoridades nacionales, provinciales y sindicales, a los efectos de conseguir el mantenimiento de tan importante fuente de trabajo. Son nuestros deseos y el de toda la población de Santa Fe, que los inconvenientes que impiden su funcionamiento normal puedan ser subsanados y que la empresa una vez recuperada, siga siendo el punto de referencia industrial de nuestra provincia", Memoria y Balance de la UISF, Santa Fe, 1968, reproducida en INSTITUTO SUPERIOR N ${ }^{\circ}$ 12, Historia industrial. Publicación de los 75 años de la Unión Industrial de Santa Fe. Borrador para estudio, Santa Fe, s/f, p. 145.

73 BELINI, Claudio y ROUGIER, Marcelo, El Estado empresario en la industria..., Op. Cit.

74 La ley se dictó en noviembre de 1967, y se reglamentó al año siguiente. Autorizaba al PEN “a arbitrar soluciones tendientes a recuperar empresas que se encontrasen en 'virtual estado de cesación de pagos' [...] El régimen preveía fundamentalmente la consolidación de pasivos fiscales y provisionales de las firmas en problemas, que además podían ser eximidas total o parcialmente del pago de intereses, recargos y multas por mora en el cumplimiento de aquellas obligaciones..." ROUGIER, Marcelo y SCHVARZER, Jorge, Las grandes empresas no..., Op. Cit., pp. 79-80. El apoderado legal de IASFSA declaraba en 1968 que los funcionarios que intervenían en la consideración de los problemas de la empresa se habían expresado a favor de que ésta ingresara al régimen de rehabilitación. Revista Tiempo, Santa Fe, 1968, No XXV, p. 11. 
meses de 1969, cuando la empresa ya había sido vendida. ${ }^{75} \mathrm{Y}$ en tercer lugar, el Directorio buscó relanzar la producción a través de la fabricación de una nueva línea propia de modelos y comprometiendo a Auto Union de Alemania para que realice nuevas inversiones. ${ }^{76}$ Sin embargo, ninguna de estas alternativas se realizó y el proceso de crisis de la empresa se manifestó irreversible. Tanto la dirección de la empresa como el gobierno provincial de Eladio Vázquez (1966-1970) comenzaron a realizar gestiones para encontrarle nuevos dueños a la planta. Finalmente en 1969, y luego de permanecer cerrada por 5 meses, la planta de Sauce Viejo volvió a activarse por la adquisición de Fiat, que decidió trasladar su línea de producción de camiones desde Córdoba. Teniendo en cuenta los inconvenientes económicos y sociales que circulaban en torno a la crisis de IASFSA, principalmente el desempleo y la caída en la actividad de subsectores asociados, la llegada de Fiat vino en definitiva a solucionar más de un problema en la región.

Las razones del fracaso de una empresa son un tema tan interesante como debatible, no solo ante los ejemplos sino también dentro de la misma teoría económica. ${ }^{77}$ En nuestro caso de estudio, a las expresiones del Directorio que tienden a ubicar en factores externos las causas de la crisis, debe sumarse la opinión de algunos ex-trabajadores entrevistados. Entre ellos encontramos una común percepción de que IASFSA cayó por razones internas. No obstante las opiniones son divergentes a la hora de reconocer cuáles fueron esas razones. Para uno de los entrevistados, IASFSA fue "como otras fábricas que aparecieron y se fundieron junto con esta, un negocio para aprovecharlo mientras podían y después arreglaban"; otra opinión señala que "el proyecto fue muy aventurero porque era imposible, no tenía prácticamente capital". ${ }^{78}$ Por otro lado, algunos remarcaron la falta de experiencia y conocimiento de la conducción de la empresa: "la mayoría de la conducción no tenía experiencia" afirma una fuente, mientras otra agrega que "el problema grave era que, salvo Huerta, ahí nadie tenía noción de fábrica" ${ }^{79}$ Otro entrevistado apuntó al aspecto tecno-productivo: "la empresa no se modernizó, seguía con la misma técnica de elaboración desde el comienzo, como que

75 El Estado nacional tampoco ingresó en el paquete accionario de IASFSA, como lo había hecho con numerosas empresas en crisis que habían sido financiadas por el Banco Industrial. Al respecto véase BELINI, Claudio y ROUGIER, Marcelo, El Estado empresario en la industria..., Op. Cit.

76 Este último proyecto consistía en reemplazar la línea de producción de DKW por un automóvil marca Audi de tipo deportivo. Debe destacarse que en 1964, Daimler-Benz había vendido la marca Auto Union a Volkswagen. Según algunas fuentes consultadas, Volkswagen eligió promover los motores de cuatro tiempos dentro de Auto Union. Por lo cual, reemplazó el desarrollo de los DKW -de dos tiempos- por autos de la marca Audi, equipados con motores de cuatro tiempos y cuatro cilindros.

77 BELINI, Claudio y ROUGIER, Marcelo, El Estado empresario en la industria..., Op. Cit., pp. 250-253

78 Opiniones de Oscar A., (entrevista del autor, realizada el 11/3/2011) y José M. respectivamente.

79 Opiniones de Hugo R. y Carlos G., respectivamente. 
hubiera sido programada para tener una vida útil determinada" ${ }^{80}$ En un testimonio también se señala la responsabilidad de los inversores extranjeros: "DKW no invirtió lo pautado, trajo maquinaria obsoleta a la nueva planta y además sobrefacturaba las partes o materiales que vendía". ${ }^{81}$ A partir del entrecruzamiento de fuentes primarias y secundarias que realizamos en este trabajo, y problematizando las opiniones de los ex-trabajadores, podemos concluir en que el comportamiento empresario de los inversores nacionales y extranjeros no alcanza por sí mismo a explicar el fracaso de IASFSA. A la par de ese factor, sin dudas importante, también actuaron factores externos como la oligopolización del mercado automotriz (que describimos anteriormente) y un escenario macroeconómico de expansión industrial aunque con numerosas marchas y contramarchas que afectaron a gran cantidad de empresas. ${ }^{82} \mathrm{~A}$ partir de la confluencia entre factores internos y externos podemos arribar a una explicación integral de la crisis en nuestro caso de estudio.

\section{Conclusiones}

Dentro de los numerosos proyectos que surgieron en el país a partir del desarrollismo y su régimen de promoción a la industria automotriz, IASFSA fue uno de los emprendimientos de capital mixto que tuvo entre sus características un capital inicial relativamente bajo en comparación a otras firmas, y una producción no diversificada que representó una pequeña cuota del mercado nacional. No fue ni el único proyecto de capital mixto ni el más importante, pero fue el único que se instaló en Santa Fe, y en una región geográfica (la zona central de la provincia) que carecía de antecedentes de grandes industrias, y por ende de cualquier tipo de economía de escala aprovechable. Las consecuencias de la presencia de IASFSA en Sauce Viejo han podido verse en estadísticas provinciales y datos acerca de su vinculación con numerosas firmas autopartistas y otros subsectores. El efecto multiplicador característico de una terminal automotriz se ve reflejado en el caso de IASFSA, y posteriormente en la década del ' 70 será amplificado con la presencia de Fiat. Además, IASFSA tuvo un efecto dinamizador en cuanto a algunos procesos de trabajo y tecnologías utilizados que fueron novedosos para el sector industrial de la región.

La empresa que estudiamos también fue un proyecto cuya conducción tuvo una particular composición tripartita: DKW aportó las maquinarias y herramientas (y con ellas gran

80 Testimonio de Rodolfo B.

81 Testimonio de José M. Vale destacar que las prácticas de incorporar maquinaria obsoleta (ya utilizada y amortizada en su país de origen) y sobrefacturar las importaciones son señaladas como prácticas comunes a muchas transnacionales que operaron en distintas ramas industriales del país. Al respecto, ver SCHVARZER, Jorge, La industria que..., Op .Cit., pp. 256-257.

$82 \mathrm{Al}$ respecto, BELINI, Claudio y ROUGIER, Marcelo, El Estado empresario en la industria..., Op. Cit. 
parte del capital de la firma), las licencias y una parte de las piezas para la fabricación de los modelos; los accionistas locales (de Buenos Aires y Santa Fe) se integraron aportando algo del capital y sus contactos políticos y empresariales en la provincia, en el país y en el exterior; y los ex-militares involucrados aportaron importantes contactos no solo con políticos y empresarios sino también con el complejo militar estatal DINFIA, que como vimos desempeñó un rol muy importante en los inicios de IASFSA. Esta composición tripartita de la conducción, claramente distinta a la que tenían por esos años las filiales en el país de las grandes automotrices, puede ser comparable a otro proyecto de capital mixto como Dinborg. La diferencia con esta firma y con el resto de los emprendimientos de capital mixto consistió en que IASFSA fue la empresa de ese tipo que mayor permanencia tuvo en el mercado automotriz nacional de la década del ' 60 . Ante un proceso de depuración de capitales y creciente oligopolización, se mantuvo diez años en el mercado. Las razones de tal fenómeno no se encuentran en la organización interna de la firma, ni en la administración de sus finanzas. Respecto a estos temas, observamos que IASFSA tuvo, en general, los mismos inconvenientes que muchas empresas industriales dentro de un contexto macroeconómico con muchos vaivenes y problemas, aún durante un ciclo expansivo de la industria. La permanencia de IASFSA en el mercado parece estar relacionada a la posición de sus modelos, principalmente el 1000S, dentro del mercado nacional. Si bien la empresa adaptó su oferta a la demanda de automóviles, al igual que las demás automotrices, pudimos observar que en el segmento de automóviles medianos-chicos IASFSA no debió competir con las automotrices más importantes, algo que si le ocurrió a SIAM. La buena recepción del modelo 1000S en la demanda y su éxito en las ventas parecerían haber sostenido resultados comerciales positivos para la empresa, que si bien no alcanzaron a evitar el paulatino deterioro financiero, por lo menos lo extendieron en el tiempo. Antes de entrar en su crisis definitiva, IASFSA ya era la única empresa de capital mixto que se sostenía en el mercado local de automotores.

La crisis definitiva no fue más que la agudización de los problemas financieros, aunque ciertamente la suspensión de las autorizaciones para importar piezas determinada por la DNA señaló su comienzo. Como analizamos en el apartado dedicado a la misma, las causas internas a la empresa no alcanzan a explicar su caída, por más responsabilidad que hayan tenido sus inversores nacionales y extranjeros. El ejemplo de SIAM Automotores, que fue un proyecto de capital mixto mucho más respaldado que IASFSA, demuestra que aún con más inversiones y mayor porción de mercado el éxito no estaba garantizado. Hasta una gran empresa como IKA también fue absorbida durante esos años. Nuestra conclusión es que para entender la crisis de IASFSA, a los factores internos de la crisis de la empresa, que sin dudas existieron, deben agregárseles factores externos como el funcionamiento del mercado automotriz y el contexto macroeconómico del país.

En definitiva, como parte de la industria automotriz en la década del '60, IASFSA tuvo obviamente características comunes al conjunto de terminales instaladas en el país. Como empresa de capital mixto, tuvo rasgos comunes a empresas como SIAM y Dinborg. Pero la 
combinación de sus rasgos particulares, relacionados a su ubicación geográfica, la composición de su conducción y su trayectoria en el mercado, hicieron de IASFSA una experiencia singular dentro de la industria automotriz en la década del ' 60 .

Recibido: 03/05/2013

Aceptado: 28/08/2013 